\title{
PERTUMBUHAN BIBIT TENGKAWANG (Shorea spp) ASAL BIJI DARI POPULASI HUTAN ALAM KALIMANTAN DI PERSEMAIAN B2PD SAMARINDA
}

(Growth of Tengkawang Seedling (Shorea spp) of Seeds from Kalimantan Natural Forest Population in B2PD Samarinda nursery)

$\mathrm{Oleh} / \mathrm{By}$ :

\section{Asef K. Hardjana dan/and Rayan}

Peneliti Balai Besar Penelitian Dipterokarpa Samarinda

\begin{abstract}
One of Dipterocarpaceae species that produces non timber forest product (NTFP) is Illipe nut or locally known as Tengkawang (Shorea spp). Tengkawang can be categorized as NTFP for food, energy and medicine (NTFP FEM). To achieve sustainability of Tengkawang seeds production, tengkawang fruit productivity and quality serious handling is needed. Genetic material collection of tengkawang species was done in natural forest population in West Kalimantan (Mount Bunga-Bekinci and Runtin river) and Central Kalimantan (Bukit Baka). Seedling was done in B2PD Samarinda nursery. The results showed that the percentage of germination were $84,09 \%, 79,97 \%$ and 70,68\% for population of Mount Bunga-Bekinci, Runtin river and Bukit Baka, respectively. From hree natural forest population three species have been identified. They are Shorea macrophyla, $\mathrm{S}$. pinanga and S. gysberstiana. The largest average diameter growth is $\mathrm{S}$. gysberstiana and S. macrophyla of natural forest population of Runtin River The largest average height growth is S. gysberstiana of natural forest population of Mount Bunga-Bekinci.
\end{abstract}

Keywords: HHBK FEM, growth, Tengkawang

\begin{abstract}
ABSTRAK
Tengkawang (Shorea spp) adalah salah satu jenis Dipterocarpaceae yang menghasilkan hasil hutan bukan kayu untuk produk makanan, obat-obatan atau kosmetik (HHBK FEM (Food, Energi and Medicine). Untuk meningkatkan produksi dan kualitas buah tengkawang yang dihasilkan dan agar pengelolaan dan pengusahaan HHBK FEM untuk makanan, obat-obatan dan kosmetik dapat berkelanjutan, diperlukan penanganan yang serius. Pengumpulan materi genetik jenis tengkawang telah dilakukan dipopulasi hutan alam di Kalimantan Barat (Gunung Bunga-Bekinci dan Sungai Runtin) dan KalimantanTengah (Bukit Baka). Penyemaian dilakukan di persemaian B2PD Samarinda. Pertsentase biji yang berkecambah di persemaian berurutan sebanyak $84,09 \%$ dan 70,68\% untuk populasi dari Gunung Bunga-Bekinci, Sungai
\end{abstract}


Runtin dan Bukit Baka. Dari tiga populasi hutan alam tersebut telah teridentifikasi untuk sementara sebanyak 3 jenis tengkawang, yaitu : Shorea macrophyla, S. pinanga dan S. gysberstiana. Pertumbuhan rataan diameter terbesar adalah $S$. gyberstiana dan S. macrophyla dari populasi hutan alam Gunung Bunga-Bekinci.

\section{Kata kunci : HHBK FEM, Pertumbuhan, Tengkawang}

\section{PENDAHULUAN}

Jenis Dipterocarpaceae adalah jenis yang sangat penting di hutan hujan tropika dan mempunyai nilai ekonomi yang tinggi dan sudah dikenal di pasaran internasional. Seperti diketahui bahwa jenis ini mendominasi dataran rendah hutan tropika basah yang meliputi Semenanjung Malaya, Kepulauan Indonesia (Sumatera dan Kalimantan), Philipina dan Thailand (Whitmore, 1989). Suku Dipterocarpaceae terdiri atas banyak jenis, diantaranya sebagian sebagai penghasil kayu. Bahkan diperkirakan hampir $25 \%$ kebutuhan kayu dunia berasal dari suku Dipterocarpaceae (Ashton, 1989), dan sebagian yang lain merupakan penghasil non kayu atau yang sering disebut Hasil Hutan Bukan Kayu (HHBK) antara lain resin, getah atau damar, tannin dan buah tengkawang.

Tengkawang (Shorea spp) adalah nama buah dan pohon dari genus Shorea yang buahnya menghasilkan minyak nabati. Karena sifatnya yang khas, lemak tengkawang berharga lebih tinggi daripada minyak nabati lain seperti minyak kelapa. Lemak Tengkawang digunakan sebagai bahan pengganti minyak coklat, bahan lipstik, minyak makan dan bahan obat-obatan (Alamendah, 2009). Pohon Tengkawang hanya terdapat di Pulau Kalimantan dan sebagian kecil Sumatera. Kayu tengkawang termasuk ke dalam golongan kayu kelas tiga atau dikenal dengan golongan kayu meranti merah (Alamendah, 2009). Tengkawang terdiri atas belasan jenis (species) diantaranya ada 13 jenis yang dilindungi dari kepunahan berdasarkan PP Nomor 7 Tahun 1999 tentang Pengawetan Jenis Tumbuhan dan Satwa, dan SK Menhut No. 261/Kpts-IV/1990 tentang perlindungan pohon tengkawang sebagai tanaman langka, jenis-jenis tersebut adalah Shorea stenoptera (tengkawang tungkul), Shorea mecystopteryx (tengkawang layar),

Shorea pinanga (tengkawang rambai), Shorea seminis (tengkawang terendak), Shorea beccariana (tengkawang tengkal), Shorea micrantha (tengkawang bungkus), Shorea palembanica (tengkawang majau), Shorea lepidota (tengkawang gunung), Shorea singkawang, Shorea stenoptera, Shorea compressa, Shorea gysberstiana dan Shorea martiana.

Tidak semua pohon tengkawang berbuah tiap tahunnya, panen raya buah tengkawang biasanya dalam periode antara 3 - 7 tahun yang terjadi sekitar bulan Juni - Agustus (Alamendah, 
2009). Oleh karena masa berbuahnya tidak setiap tahun, maka jarang yang membudidayakan jenis tengkawang ini. Seperti diketahui sampai sekarang biji tengkawang memiliki nilai manfaat yang tinggi bagi masyarakat yang berdomisili di sekitar hutan di Kalimantan Barat yang masih menggantungkan sebagian hidupnya dari hutan. Selain itu, akhir-akhir ini pohon tengkawang semakin langka karena banyak yang ditebang untuk dipergunakan sebagai bahan bangunan dan kayu tengkawang ini memiliki nilai jual sekitar Rp.600.000/m³ (Alamendah, 2009).

Dengan kondisi tersebut, maka tengkawang menjadi salah satu jenis unggulan yang perlu mendapat perhatian khusus dalam hal kelestariannya, peningkatan produktivitas dan kualitas sesuai dengan kebutuhan konsumen, sehingga program pemuliaan merupakan salah satu pendekatan yang dapat dilakukan untuk memenuhi harapan tersebut. Berkaitan dengan hal tersebut, tujuan dari kegiatan ini adalah untuk menghasilkan informasi awal pertumbuhan materi genetik (biji) jenis tengkawang dari populasi hutan alam yang disemaikan di persemaian. Melalui penelitian ini diharapkan tersedia informasi dan teknologi awal untuk pembudidayaan maupun pengembangan jenis tengkawang yang berasal dari populasi hutan alam Kalimantan di persemaian, sebelum dilakukan penanaman dan pengembangan lebih lanjut di lapangan.

\section{METODOLOGI}

\section{A. Lokasi dan Waktu Penelitian}

Lokasi pengumpulan materi genetik tengkawang berasal dari 3 populasi hutan alami yaitu Gunung Bunga-Bekinci dan Sungai Runtin di Kalimatan Barat, serta Bukit Baka di Kalimantan Tengah. Lokasi penelitian pembibitan biji tengkawang dilakukan di persemaian Balai Besar Penelitian Dipterokarpa (B2PD) Samarinda. Waktu penelitian dilakukan selama 8 bulan dari bulan Maret s/d Nopember 2010.

\section{B. Bahan dan Peralatan}

Bahan yang digunakan untuk kegiatan penelitian di persemaian adalah label benih, polybag, plastik sungkup, pipa plastik, bambu, top soil, pasir, sekam padi, sarlon, pupuk, fungisida, insektisida, tali tukang, paku, kayu dan terpal. Sedangkan peralatan yang digunakan adalah pita ukur, penggaris, caliper, cangkul, sekop, palu, cutter, gunting, gunting stek, parang, ayakan dan kamera. 


\section{Prosedur Kerja}

Tahapan pembibitan di persemaian dilakukan setelah materi genetik (biji) sudah terkumpul di persemaian, biji-biji tersebut diseleksi dan dipilah-pilah berdasarkan identitasnya di lapangan setelah itu dilakukan kegiatan sebagai berikut:

- Benih yang sudah disiapkan, disemaikan ke dalam bedeng tabur atau polybag yang telah diisi media semai untuk setiap lokasi, masing-masing diberi label identitas sesuai dengan nomor identitas lokasi.

- Pemeliharaan dilakukan secara rutin meliputi: penyiraman, penyiangan, penyemprotan fungisida atau insektisida apabila ada gejala serangan hama dan penyakit, pembukaan naungan/sarlon sesuai dengan kebutuhan sinar matahari bagi pertumbuhan bibit dan lainnya.

- Pengamatan kondisi bibit dilakukan setiap minggu sekali sampai bibit siap tanam.

- Pengukuran pertumbuhan bibit dilakukan sebelum bibit ditanam di lapangan, hal ini dilakukan untuk mengetahui informasi pertumbuhan dari setiap identitas berdasarkan lokasi populasinya.

- Parameter yang diukur dalam penelitian ini adalah persentase hidup bibit (\%) dari mulai disemaikan sampai siap tanam, tinggi $(\mathrm{cm})$ dan diameter $(\mathrm{cm})$ bibit untuk mengetahui kualitas kekokohan bibit (diameter/tinggi bibit).

Pengolahan dan analisis data yang dilakukan hanya pada lingkup perhitungan jumlah materi genetik (biji) yang menjadi bibit tanaman (persentase hidup) dan rata-rata pertumbuhan bibit (diameter dan tinggi) berdasarkan masing-masing jenis dan lokasi populasi hutan alam. Berikut formula yang digunakan dalam menghitung persentase hidup biji yang tumbuh menjadi bibit, yaitu:

$$
\text { Persentase hidup }=\frac{\text { Jumlah biji yang tumbuh (bibit) }}{\text { Jumlah seluruh biji yang disemaikan }} \times 100 \%
$$

\section{HASIL DAN PEMBAHASAN}

Materi genetik (biji) tengkawang (Shorea spp) yang terkumpul merupakan hasil dari kegiatan eksplorasi pada 3 (tiga) populasi hutan alami, yaitu di populasi Gunung Bunga dan Sungai Runtin di areal IUPHHK PT Suka Jaya Makmur (PT. SJM) Provinsi Kalimantan Barat, serta populasi Bukit Baka di areal IUPHHK PT. Sari Bumi Kusuma (PT. SBK) Provinsi Kalimantan Tengah. Biji tengkawang yang terkumpul kemudian dibawa ke persemaian untuk disemaikan, namun sebelum dilakukan penyemaian biji-biji tersebut diseleksi dan dipilah-pilah berdasarkan pohon induk dan lokasi populasinya. 


\section{A. Pembibitan Tengkawang (Shorea spp).}

Pembibitan tengkawang dimaksudkan untuk mempersiapkan bibit tengkawang dari penyemaian biji hingga siap tanam dalam kegiatan penanaman di lapangan, baik dalam skala reboisasi (penghijauan) maupun penelitian untuk jenis tersebut. Pembibitan tengkawang yang dilakukan dalam penelitian ini dimulai dari kegiatan perkecambahan biji tengkawang yang dikecambahkan ke dalam bedeng tabur yang berisikan media pasir dan ditutup sungkup dari bahan plastik selama 2 bulan setelah berkecambah dan menjadi semai (bibit). Biji tengkawang ini harus cepat ditabur untuk dikecambahkan setelah tiba dari lapangan karena biji tengkawang termasuk golongan recalcitran seed atau golongan biji yang jika kadar air dalam biji mengalami kering maka biji tersebut tidak akan tumbuh (mati), sehingga golongan biji ini tidak mengalami masa dormansi yang cukup lama seperti biji dari jenis-jenis pionir. Kemudian bibit disapih ke dalam polybag yang telah terisi media berupa campuran top soil dan sekam padi, untuk penyesuaian dengan lingkungan bibit disungkup hingga bibit tahan terhadap sinar matahari dan suhu udara sekitar persemaian (Gambar 1).

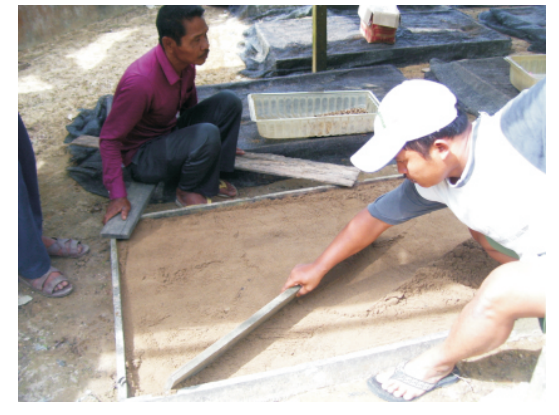

(A)

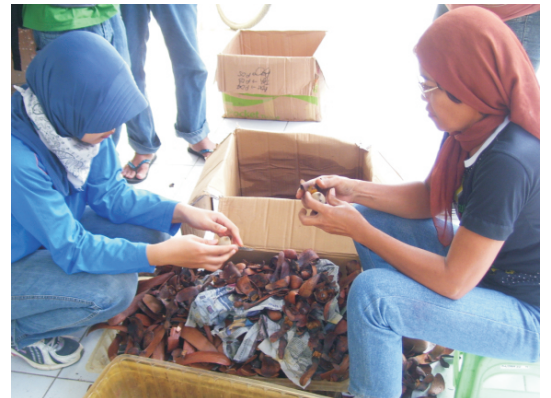

(B)

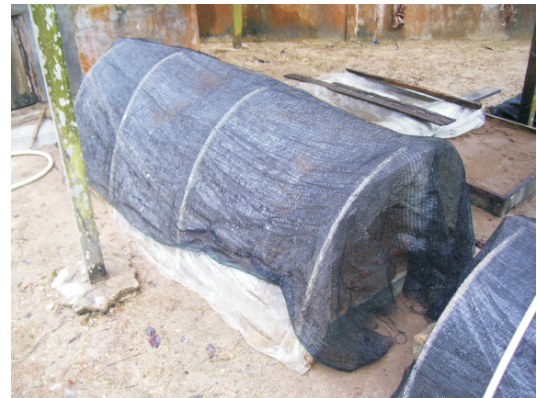

(C)

Gambar(Figure) 1. Mempersiapkan media kecambah di bedeng tabur (A); Seleksi dan pemilahan biji tengkawang (B); Bedeng tabur yang berisi biji diberi sungkup (C). (Getting things germination media at barrack sows (A); Selection and tengkawang's seed elect (B); Barrack sows that meaty seed was given to shaped cover $(C)$.)

Persentase perkecambahan biji tengkawang di catat sejak dari jumlah biji tengkawang yang dikecambahkan hingga berkecambah dan bibit siap sapih, kemudian disapih ke polybag hingga bibit tidak disungkup lagi. Persentase kecambah biji tengkawang dari populasi Gunung Bunga-Bekinci 84,09\%, populasi Sungai Runtin 73,97\% dan populasi Bukit Baka 70,68\% (Tabel 1). Di bulan Nopember 2010 bibit tengkawang dipersemaian sudah berumur kurang lebih 9 bulan dan dalam kondisi sehat. 
Tabel (Table) 1. Persentase hidup biji tengkawang dari 3 populasi hutan alam yang berbeda provenan (Survival percentage of tengkawang seeds from 3 natural forest populations from different provenance).

\begin{tabular}{|c|l|c|c|c|c|}
\hline $\begin{array}{c}\text { No } \\
(\text { Num } \\
\text { ber })\end{array}$ & \multicolumn{1}{|c|}{$\begin{array}{c}\text { Populasi } \\
\text { (Population) }\end{array}$} & $\begin{array}{c}\text { Jumlah } \\
\text { Pohon Induk } \\
\text { (Number of } \\
\text { mother trees })\end{array}$ & $\begin{array}{c}\text { Jumlah Biji } \\
\text { yang Ditabur } \\
\text { (Sewn seeds) }\end{array}$ & $\begin{array}{c}\text { Jumlah yang } \\
\text { Berkecambah } \\
\text { (Germinated seed) })\end{array}$ & $\begin{array}{c}\% \\
\text { Kecambah } \\
\text { (\%ermination) } \\
(\%)\end{array}$ \\
\hline 1 & G. Bunga-Bekinci, Kalbar & 20 & 1012 & 851 & 84,09 \\
\hline 2 & Sungai Runtin, Kalbar & 23 & 1264 & 935 & 73,97 \\
\hline 3 & Bukit Baka, Kalteng & 39 & 2374 & 1678 & 70,68 \\
\hline
\end{tabular}

Kegagalan pada pembibitan tengkawang dalam penelitian ini dimulai pada saat perkecambahan. Biji yang tidak berkecambah karena mengalami kekeringan maupun pembusukan ditandai dengan munculnya jamur di sekitar biji yang busuk. Pada periode penyapihan, bibit tidak mengalami kematian tapi mengalami stress ringan yang ditandai dengan terjadinya penghitaman/pengeringan pada pucuk dan daun rontok. Namun demikian setelah beberapa minggu bibit dapat normal kembali.

Penangan bibit tengkawang di persemaian, dimulai sejak pengecambahan biji hingga bibit siap tanam yang digambarkan dalam Gambar 2.

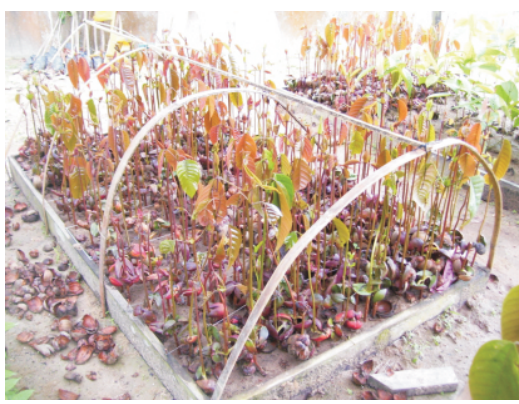

(A)

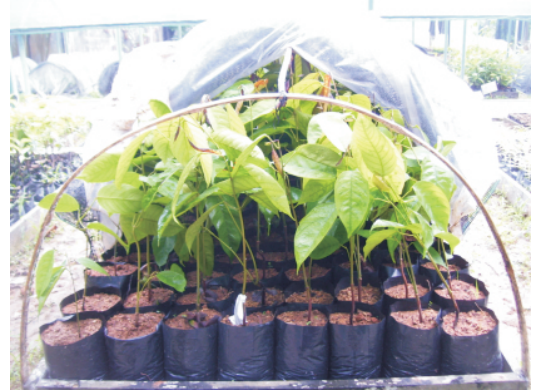

(B)

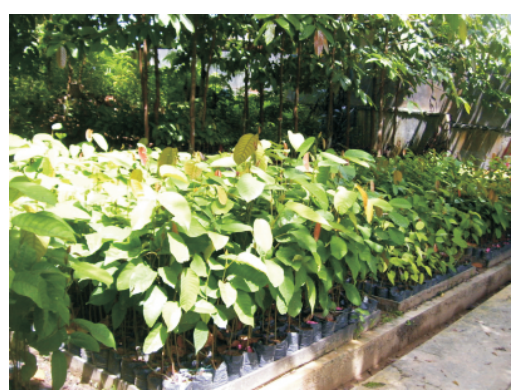

(C)

Gambar (Figure) 2. Biji tengkawang yang telah berkecambah (A); Bibit tengkawang yang telah disapih dan harus diberi sungkup (B); Bibit tengkawang yang telah lepas sungkup dan penyesuaian dengan lingkungan sekitar (C) (Tengkawang's seed already germinates (A); tengkawang's seed already been weaned and has to be given by shaped cover (B); tengkawang's seed already takes down shaped cover and fit with their surrounding $(C)$.) 


\section{B. Identifikasi dan Pertumbuhan Bibit Tengkawang (Shorea spp).}

Identifikasi jenis bibit tengkawang secara ilmiah dan kemudian dipilah-pilah berdasarkan asal populasinya dilakukan guna untuk mengetahui keragaman jenis dari bibit tengkawang yang telah dikumpulkan pada beberapa populasi hutan alam. Selain itu, juga berfungsi untuk memberikan identitas kepada bibit tengkawang berdasarkan pohon induk dan provenannya, sehingga bila bibit digunakan dalam kegiatan penelitian pemuliaan dapat teridentifikasi kualitas bibitnya berdasarkan dari pohon induk dan provenannya. Hasil identifikasi bibit tengkawang di persemaian diketahui bahwa dari tiga populasi hutan alami tersebut teridentifikasi untuk sementara sebanyak 3 jenis tengkawang, yaitu : Shorea macrophyla, S. pinanga dan S. gysberstiana. Populasi hutan alami Bukit Baka Kalteng yang memiliki keragaman jenis sebanyak 3 jenis tengkawang, sedangkan pada populasi Gunung Bunga-Bekinci dan Sungai Runtin Kalbar hanya memiliki 2 jenis tengkawang yaitu S. macrophyla dan S. gysberstiana (Tabel2).

Tabel (Table) 2. Jumlah bibit per jenis dari tiga populasi provenan tengkawang (Total seed per species from three tengkawang populations provenance).

\begin{tabular}{|c|l|c|c|c|}
\hline $\begin{array}{c}\text { No } \\
\text { (Num } \\
\text { ber })\end{array}$ & \multicolumn{1}{|c|}{$\begin{array}{c}\text { Populasi } \\
\text { (Population) }\end{array}$} & \multicolumn{3}{|c|}{ Jumlah Bibit Per Jenis (Number of seeds / species) } \\
\cline { 2 - 5 } & S. macrophyla & S. pinanga & S. gysberstiana \\
\hline 1 & G. Bunga-Bekinci, Kalbar & 761 & - & 90 \\
\hline 2 & Sungai Runtin, Kalbar & 888 & - & 47 \\
\hline 3 & Bukit Baka, Kalteng & 784 & 481 & 403 \\
\hline
\end{tabular}

Pengamatan terhadap bibit tengkawang yang berhasil dikumpulkan selanjutnya adalah identifikasi, pengukuran dan pemberian identitas masing-masing berurutan untuk mengetahui jenisnya, pertumbuhannya dan penelitian jangka panjang yang dilukiskan pada Gambar 3 .

Dari hasil identifikasi yang merujuk pada bibit tengkawang di persemaian dapat diketahui bahwa jenis $S$. macrophyla mendominasi bibit terbanyak pada 3 populasi hutan alam, sedangkan S. stenoptera belum dapat teridentifikasi dengan jelas, hal ini dikarenakan ada kemiripan yang dekat dengan $S$. gysberstiana. Shorea stenoptera merupakan jenis tengkawang yang menjadi unggulan dan mempunyai nama pasar yang cukup terkenal dengan kualitas biji yang baik (Sumadiwangsa, 2001), sehingga menjadi suatu pembahasan yang penting bila diketahui bahwa jenis ini sudah mulai berkurang keberadaannya di hutan alam. 
Pengukuran awal pertumbuhan (diameter dan tinggi) bibit tengkawang dilakukan berdasarkan jenis, pohon induk dan provenannya (populasi hutan alam). Kegiatan ini merupakan bagian dari pengamatan bibit di persemaian untuk mengetahui kondisi pertumbuhan bibit dalam periode waktu tertentu, selain itu ketertiban dalam pengukuran ini harus juga diterapkan agar dalam penyusunan bibit tidak tertukar penempatannya dengan identitas bibit yang lain.

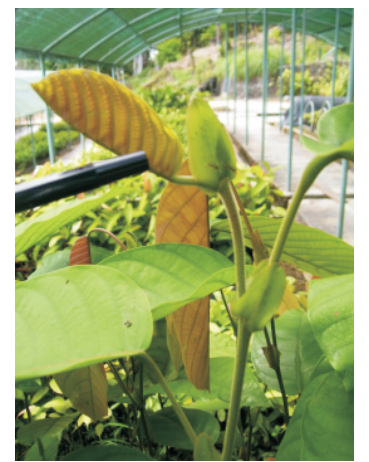

(A)

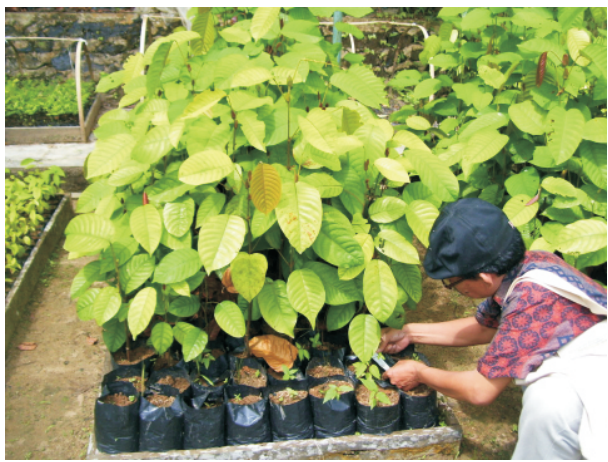

(B)

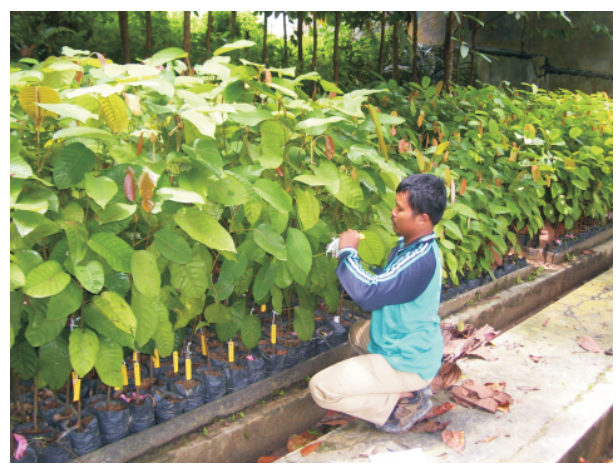

(C)

Gambar (Figure) 3. Identifikasi jenis bibit tengkawang (A); Pengukuran dimensi pertumbuhan bibit tengkawang (B); Pemberian identitas bibit tengkawang (C). (Species identification of tengkawang seedling (A); Measurement of growth dimensions of tengkawang seedling (B); ID application of tengkawang seedling (C).)

Dari hasil pengukuran pertumbuhan bibit tengkawang dapat diketahui bahwa jenis S. macrophyla memiliki diameter rata-rata berkisar $0,59-0,89 \mathrm{~cm}$ dengan tinggi rata-rata berkisar 64,29 - 71,16 cm. Pada jenis $S$. gysberstiana memiliki diameter rata-rata berkisar $0,71-0,78 \mathrm{~cm}$ dengan tinggi rata-rata berkisar 48,98 - 79,86 cm. Untuk jenis $S$. pinanga memiliki diameter ratarata berkisar 0,47 - 1,11 cm dengan tinggi rata-rata berkisar 46,16-79,51 cm (Gambar 4 dan 5). Shorea gysberstiana dan S. macrophyla dari populasi hutan alam Sungai Runtin memiliki pertumbuhan diameter yang lebih besar dibandingkan dengan bibit tengkawang sejenisnya dari populasi hutan alam Gunung Bunga-Bekinci dan Bukit Baka (Gambar 4). Pada pertumbuhan tinggi, Shorea gysberstiana dari populasi hutan alam Gunung Bunga-Bekinci yang memiliki pertumbuhan tinggi yang tertinggi, kemudian diikuti oleh S. macrophyla dari populasi hutan alam Sungai Runtin (Gambar 5). Pada S. pinanga dari populasi hutan alam Bukit Baka memiliki rata-rata diameter $0,47 \mathrm{~cm}$ dan rata-rata tinggi $46,16 \mathrm{~cm}$. 


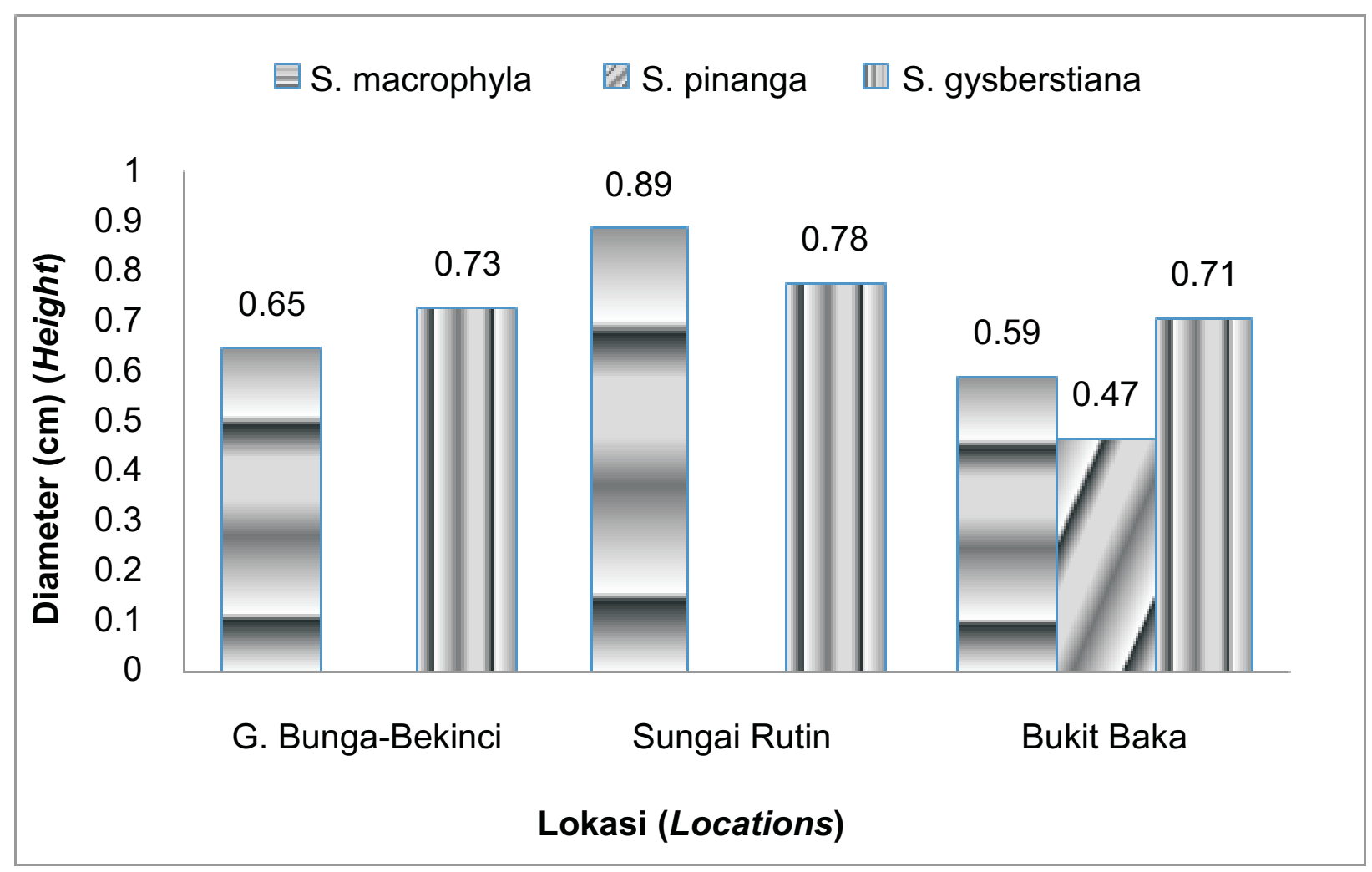

Gambar (Figure) 4. Rataan diameter jenis tengkawang dari 3 populasi hutan alam di persemaian (Average diameter of Tengkawang species in nursery originated from natural forest population). 


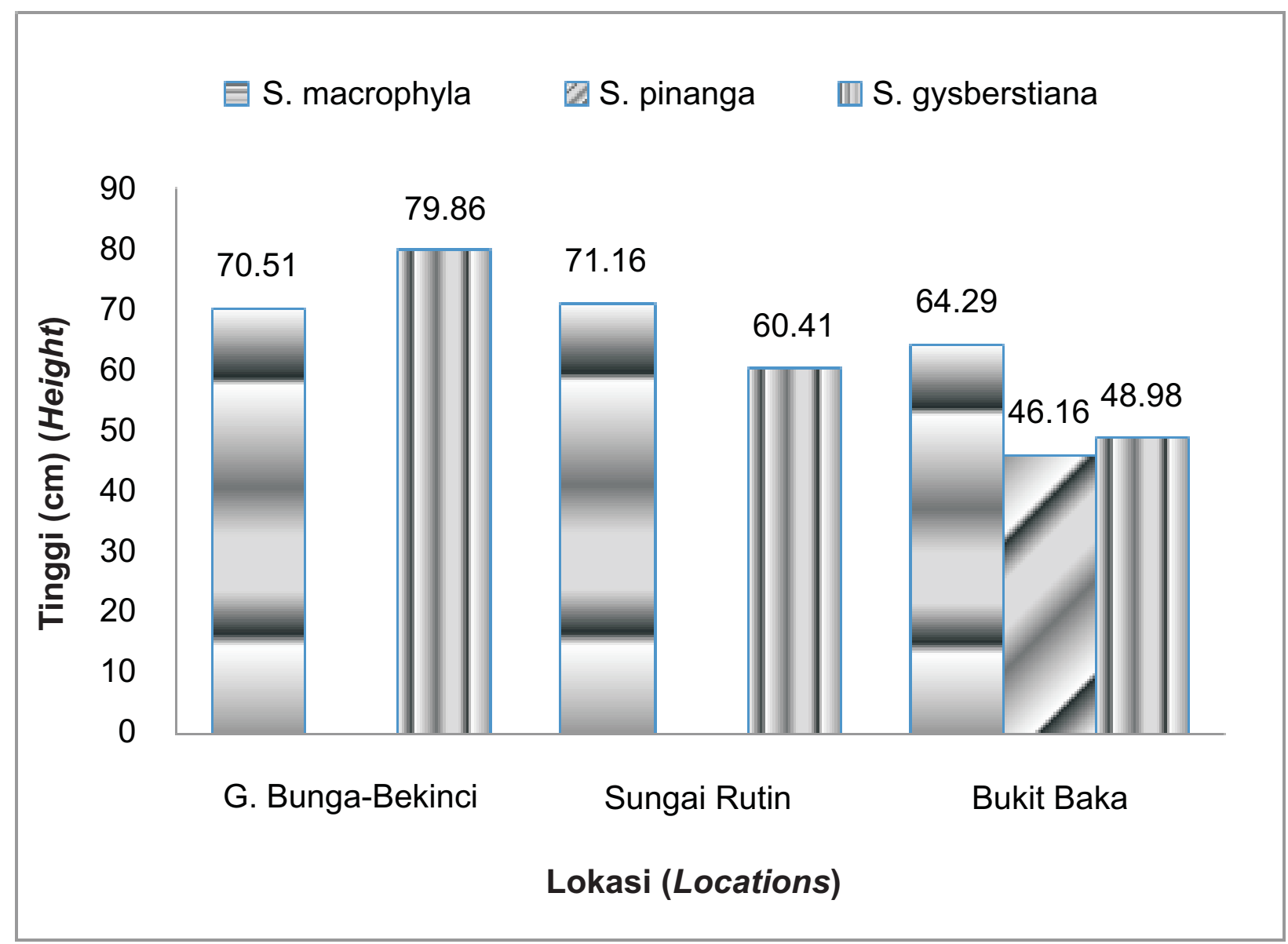

Gambar (Figure) 5. Rataan tinggi jenis tengkawang dari 3 populasi hutan alam di persemaian (Averager height of Tengkawang species in nursery originated from natural forest population).

Hasil pengukuran pada Gambar 4 dan 5 merupakan informasi awal dari data pertumbuhan bibit beberapa jenis tengkawang di persemaian. Dari penelitian awal ini diharapkan dapat menghasilkan bibit-bibit unggul yang tidak hanya dilihat dari kecepatan pertumbuhannya saja, namun yang lebih utama adalah hasil dari uji analisis kualitas minyak dari biji tengkawang terbaik pada beberapa populasi tersebut untuk menjadi bibit unggul yang layak dikembangkan dan diuji lanjutan di lapangan.

\section{KESIMPULAN}

1. Persentase kecambah biji tengkawang dari populasi Gunung Bunga-Bekinci $84,09 \%$, populasi Sungai Runtin 73,97\% dan populasi Bukit Baka 70,68\%.

2. Diketahui dari 3 populasi hutan alam tersebut telah teridentifikasi untuk sementara sebanyak 3 jenis tengkawang, yaitu : Shorea macrophyla, S. pinanga dan S. gysberstiana. Jenis S. macrophyla mendominasi bibit terbanyak pada 3 populasi hutan alam, secara berurutan jumlah 
bibit dari populasi Gunung Bunga-Bekinci, Sungai Runtin dan Bukit Baka adalah 761 bibit, 888 bibit dan 784 bibit.

3. Shorea macrophyla memiliki diameter rata-rata berkisar $0,59-0,89 \mathrm{~cm}$ dengan tinggi rata-rata berkisar 64,29-71,16 cm, Shorea gysberstiana mencapai diameter rata-rata berkisar 0,71-0,78 cm dengan tinggi rata-rata berkisar 48,98-79,86 cm dan Shorea pinanga memiliki diameter ratarata berkisar 0,47 - 1,11 cm dengan tinggi rata-rata berkisar 46,16-79,51 cm. Shorea gysberstiana dan S. macrophyla dari populasi hutan alami Sungai Runtin memiliki pertumbuhan diameter yang lebih besar dibandingkan dengan bibit tengkawang sejenisnya dari populasi hutan alami lainnya, sedangkan pada pertumbuhan dimensi tinggi, Shorea gysberstiana dari populasi hutan alam Gunung Bunga-Bekinci yang memiliki pertumbuhan tinggi yang tertinggi, kemudian diikuti oleh S. macrophyla dari populasi hutan alam Sungai Runtin.

\section{UCAPAN TERIMA KASIH}

Penulis menyampaikan terima kasih kepada Pimpinan dan karyawan PT Alas Kusuma Group yang membawahi PT Sari Bumi Kusuma di Kalimantan Tengah dan PT Suka Jaya Makmur di Kalimantan Barat yang telah membantu dalam kegiatan pengumpulan materi genetik tengkawang ini. Terima kasih juga kepada Sri Soegiarto, M.Si, Giono, S.Hut, Zul Arifin, S.Hut dan Sukir yang membantu dalam kegiatan eksplorasi dan pengumpulan materi genetik di lapangan. Dan Ucapan terima kasih juga kepada Supriadi yang membantu dalam kegiatan pembibitan dan pengamatan bibit tengkawang di persemaian.

\section{DAFTAR PUSTAKA}

Alamendah. 2009. Pohon Tengkawang Berbuah 7 Tahun Sekali. Website: http://alamendah.wordpress.com/pohon-tengkawang-berbuah-7-tahun-sekali. Diakses tanggal 18 Nopember 2009.

Ashton, P.S. (1989). Dipterocarp Reproductive Biology. In Tropical Rain Forest Ecosystem and Ecological Studies edited Lieth, H. and Warger, M.J.A. Elsevier Amsterdam-Oxford-New York-Tokyo. P 219-240.

Dephut, 2004. Kamus Pemuliaan Pohon. Direktorat Jenderal Rehabilitasi Lahan dan Perhutanan

Sosial. Direktorat Perbenihan Tanaman Hutan. Departemen Kehutanan. Jakarta. April 2004.

Sumadiwangsa E. 2001. Nilai dan Daya Guna Penanaman Pohon Tengkawang (Shorea spp.) di Kalimantan. Buletin Vol. 2 No. 1 Th 2001. 
Whitmore, T.C. (1989). South Asian Tropical Forest. In H. Leith and M.J.A. (ed.) Tropical Rain Forest Ecosystem Elsevier, Amesterdam. P. 195-218.

Yasman I. dan Hernawan, 2002. Manual Persemaian Dipterocarpaceae. Badan Penelitian dan Pengembangan Departemen Kehutanan, Tropenbos International, SFMP (GTZ), APHI, IFSP(DANIDA). Jakarta . November 2002. 